\title{
Evaluation of Soybean genotypes for yield and other economically important traits under rainfed condition
}

\author{
Doulat Baig ${ }^{1}$, Haris Khurshid ${ }^{1}$, Muhammad Arshad ${ }^{1}$, Sohail Ahmad \\ Jan $^{1,2^{*}}$, Mubashir Ahmad Khan ${ }^{1}$ and Nazakat Nawaz ${ }^{1}$ \\ 1. Oil Seed Research Program, National Agricultural Research Centre (NARC), Islamabad-Pakistan \\ 2. Department of Biotechnology, Quaid-i-Azam University, Islamabad-Pakistan \\ Corresponding author's email: sohailahmadjan3@gmail.com; sjan.parc@gmail.com \\ Citation \\ Doulat Baig, Haris Khurshid, Muhammad Arshad, Sohail Ahmad Jan, Mubashir Ahmad Khan and Nazakat Nawaz. \\ Evaluation of Soybean genotypes for yield and other economically important traits under rainfed condition. Pure \\ and Applied Biology. Vol. 7, Issue 1, pp1-7. http://dx.doi.org/10.19045/bspab.2018.70001
}

\begin{tabular}{llll}
\hline \hline Received: 04/09/2017 & Revised: 20/12/2017 & Accepted: 25/12/2017 & Online First: 01/01/2018 \\
\hline
\end{tabular}

\section{Abstract}

A study having 14 genotypes of Soybean was conducted during years 2013 and 2014 to select suitable high yielding and early maturing genotypes. The data were recorded for plant height, pods per plant, days to flowering, days to maturity, hundred seed weight, oil content and seed yield $(\mathrm{kg} / \mathrm{ha})$. The results revealed significant differences for all the traits studied. The genotype Callend produced the tallest plant $(78 \mathrm{~cm})$ during 2013. In year 2014, genotype No. $6(77 \mathrm{~cm})$ and Aust 94-1 $(77 \mathrm{~cm})$ produced the tallest plants with maximum height. Genotype SS-129 produced maximum number of pods per plant during 2013. In 2013 Callend, SS-129 and Lochlon produced flower earlier whereas in 2014 the NARC-2 showed earliest flowering. In 2013, maximum days to maturity were taken by No. 6 and minimum days were taken by NARC-2. In 2014 NARC- 2 and HM-8468 proved to be the earliest in maturity among the entries. In 2013 maximum hundred seed weight was recorded in Ajmeri followed by Callend. However, in 2014 highest hundred seed weight was produced by genotype 2429-3130. HM-8468 gave the highest oil content both in 2013 and 2014. The maximum seed yield was recorded in Ajmeri followed by Calland during 2013. In 2014, the highest yield was produced by variety NARC-2 followed by Ajmeri. We recommend wide scale germplasm characterization for selecting parental lines to develop climate smart, disease resistant and high yielding varieties.

Keywords: Genetic diversity; Rainfed; Soybean; Varietal evaluation; Yield components

Introduction

Soybean (Glycine max (L.) Merr.) is one of the important oilseed crop and grown all over the world. It contained maximum amount of protein and other important essentials vitamins that play important role in our daily life. It is also an important cash crop for our industry and also used as a biofuels [1]. For continuous improvement of this crop, it is important to develop new plant species against biotic and abiotic stress resistant lines through efficient genetic diversity methods [2-5]. The genetic variability among different germplasm can be studied though by measuring the differences/similarity among different quantitative traits of Soybean 
genotypes [6, 7]. Therefore, genetic diversity study plays a key role to study variability among different germplasm and to select improved genotypes [8-14].

Some researchers have characterized different Soybean genotypes with aim to study agro-morphological based variations. For example Khan et al. [15] evaluated full duration cultivars of Soybean for sowing in the orchards and irrigated lands of Malakand. They found that Epps and 76-2109 gave significantly higher yields than that of Bragg (commercial check). Both varieties matured 5-15 days earlier, with better quality seed and good germination percentage. However, it was also observed that plant population directly affected plant height and inversely affected pod number/plant. Khan et al. [16] studied grain yield potential of eight mid duration varieties of Soybean. Differences among the average values for days to flowering, days to maturity, plant height, pods/plant, 100-grain weight and grain yield were statistically significant. Days to flowering ranged from a minimum of 31.3 days (Century) to a maximum of 39.0 days (Ajmeri). Maximum days to maturity (100.3) were taken by Ajmeri followed by Malakand96 with 97.7 days, while the minimum of 84 days were taken by Calland and Century. Tallest plants were produced by variety Malakand-96 $(82 \mathrm{~cm})$. Jin et al. [17] studied a new sprout-Soybean cultivar, "Wonhwang" at the Honam Agricultural Research Institute (HARI) in 2005. The preliminary, advanced, and regional yield trials for evaluation and selection of Iksan45 were carried. This cultivar has a determinate growth habit with purple flower, grayish brown pubescence, grayish brow hilum, and small seed size (10.0 grams per 100 seeds). The maturity date of Wonhwang is 7 days earlier than that of the check variety, Pungsan. It has good seed quality for Soybean-sprout, and resistance to lodging. The average yield of "Wonhwang" was $2.80 \mathrm{MT} / \mathrm{ha}$, which was higher by $4 \%$ than "Pungsannamulkong" at the regional yield trials. Various morph-biochemical methods were tested by other researchers to screen best plant genotypes [18-23]. In present study we have evaluated fourteen diverged elite Soybean genotypes for two year experiments, in order to find out the suitable high yielding and early maturing genotypes. The resulted novel genotypes will be useful for further breeding program of this important plant species.

\section{Materials and methods}

The experiment comprised 14 Soybean promising advance lines viz. Callend, SS129, E-1092, Lochlan, E-1531, No-3702, Amcor, Aust 94-1, TN-81-124, HM-8468, 2429-3130, No-6, NARC-2 and Ajmeri. Experimental material was planted in Randomized Complete Block design with three replications at NARC, Islamabad in year 2013 and 2014. A Plot size of $9.6 \mathrm{~m}^{2}$ was used.The entries were planted keeping row to row and plant to plant distance of $45 \mathrm{~cm}$ and $5 \mathrm{~cm}$, respectively. Seed rate of $100 \mathrm{~kg} / \mathrm{ha}$ was used. Crop was planted during $3^{\text {rd }}$ week of July during both years. All other agronomic practices including ploughing, irrigation, fertilizer, insecticides etc. were performed as recommended. The crop was protected from insect pest and weeds through application of pesticides and mechanical weeding. Crop was harvested, sundried and threshed in the end of November. Agronomic data for plant height, number of plants per plot, number of pods per plant, days to flowering, days to maturity, 100 seed weight, oil content, and seed yield were collected and analyzed. Also, oil content was quantified by Soxhlet apparatus extraction using hexane as extraction solvent (boiling point $68^{\circ} \mathrm{C}$ ) by using method of Arif et al. [24]. Seeds were dried at $103 \pm 2^{\circ} \mathrm{C}$ until water content was reduced to $10 \%(\mathrm{w} / \mathrm{w})$. Three extraction cycles $(4+2+2$ hrs $)$ were carried out to completely recover oil from seeds. Seeds were carefully grounded after each extraction 
cycle and percentage of the collected oil in the seeds was determined gravimetrically and expressed as a weight $\%$ relative to initial weight of the raw castor bean seeds. Data was subjected to analysis of variance [25] to assess the effect of genotypes on various parameters studies.

\section{Results and discussion}

\section{Plant Height}

Plant height recorded on 14 entries revealed significant difference in both years. In 2013, plant height ranged from 30 to $81 \mathrm{~cm}$ (Table 1). Maximum plant height was recorded in E.1092 $(81 \mathrm{~cm})$ followed by callend, TM81.142, E-1531 and No. 3702 with 78, 77, 73 and $71 \mathrm{~cm}$, respectively. Minimum plant height was recorded in NARC-2 $(30 \mathrm{~cm})$. In year 2014, the Soybean genotypes did not differ significantly from each other (Table 2) for plant height.In the year 2014 the plant height was ranged from 77 to $62 \mathrm{~cm}$ (Table 2). Maximum Plant height was recorded in Aust 94-1 (77 cm) followed SS-129, NO 3702, HM-8468 with plant height of 76, 76 and 76 respectively. Minimum plant height was recorded in NARC-2(62 cm). Akande et al. [19] and Iqbal et al. [6] also claimed significant differences among Soybean genotypes for plant height.

\section{Pods per plant}

Number of pods per plant has significant role in Soybean yield. In our experiment number ofpods per plant was significant in both years (Table 1 \& 2). In 2013 maximum number of pods per plant was recorded in Ajmeri (116 pods) followed by SS-129 (111 pods), E.1092, Callend, 2429-3130 and Iochlon with 111, 105, 101, 101, and 95 pods per plant respectively, while minimum Pods per plant were recorded in HM 8468 (55) (Table 1).In 2014 range of number pods per plant was 72 to119 (Table 2). The genotypes HM8468 and Ajmeri produced maximum pods (119) followed by TN-81-124 (109) while minimum Pods per plant were recorded in NARC-2 (72). The results of this study also in line the previous studies Khan et al. [16] and Burli et al. [26]. In these studies they also observed significant variations among Soybean genotypes for number of pods per plant.

\section{Days to flowering}

In 2013 (Table 1) the data recorded on days to flowering on 14 entries of Soybean revealed significant difference, the maximum days taken to flowering recorded in TN.81.142 (49 days) followed by No .6, (48days) while minimum days to flowering was taken by Callend (43days). In 2014 effect of genotypes on $50 \%$ flowering was also significant. The maximum days taken to flowering recorded in TN-81-124(54 days) followed by E 1092,(51days) and Callend, SS-192(49days) while minimum days taken to flowering recorded in NARC-2(40 days) (Table 2). These results suggests different genetic background among the 65 Soybean lines studied for days to flowering, Veni et al. [27] also claimed that the plant genotypes significant role on days to flowering.

\section{Days to maturity}

Maturity had also significant role in any crop. However, short duration and high yielding varieties are preferred in all field crops. Days to maturity recorded on 14 entries of Soybean revealed significant difference and ranged from 94 to 103 days in 2013 (Table 1). Maximum days taken to maturity were recorded in three varieties viz. Callend, SS129, and TN -81. 124 (103 days) followed by No.3702 (102 days) and NARC-2 (101 days). The genotype E-1531 taken minimum days to maturity (94 days) was taken to maturity by. In 2014 maximum days taken to maturity was recorded in No-6(101 days) followed by E1092 (99 days). Minimum days taken to maturity were recorded in NARC-2 (90 days). Our results are similar to those reported by the findings of Arshad et al. [28] and Ashraf et al. [29] who observed significant difference among the genotype for days to maturity. 
Baig et al.

Table 1. Mean values of different parameters of Soybean genotypes during 2013 at NARC

\begin{tabular}{|c|c|c|c|c|c|c|c|c|}
\hline Entry No. & $\begin{array}{c}\text { Plant } \\
\text { Height } \\
(\mathbf{c m})\end{array}$ & $\begin{array}{c}\text { Plant/ } \\
\text { Plot } \\
\text { (No.) }\end{array}$ & $\begin{array}{c}\text { Pods/ } \\
\text { Plant } \\
\text { (No.) }\end{array}$ & $\begin{array}{c}\text { Days to } \\
\text { Flowering } \\
\text { (Days) }\end{array}$ & $\begin{array}{c}\text { Days to } \\
\text { Maturity } \\
\text { (Days) }\end{array}$ & $\begin{array}{c}\text { Seed } \\
\text { Yield } \\
\text { (kg/ha) }\end{array}$ & $\begin{array}{c}\text { 100 Seed } \\
\text { Weight } \\
\text { (g) }\end{array}$ & $\begin{array}{c}\text { Oil } \\
\text { Content } \\
(\mathbf{\%})\end{array}$ \\
\hline Callend & 78 & 124 & 101 & 43 & 103 & 2249 & 11.07 & 18.3 \\
\hline SS-129 & 65 & 78 & 111 & 44 & 103 & 831 & 9.53 & 18.4 \\
\hline E-1092 & 81 & 136 & 105 & 47 & 103 & 1161 & 8.10 & 17.4 \\
\hline Lochlon & 62 & 95 & 95 & 45 & 97 & 928 & 8.57 & 17.9 \\
\hline E-1531 & 73 & 134 & 72 & 45 & 94 & 2160 & 11.03 & 18.9 \\
\hline No.3702 & 71 & 103 & 72 & 46 & 102 & 1015 & 8.93 & 16.2 \\
\hline Amcor & 61 & 106 & 72 & 46 & 99 & 576 & 7.70 & 16.8 \\
\hline Aust 94-1 & 57 & 87 & 63 & 45 & 98 & 802 & 9.57 & 18.2 \\
\hline TN-81-124 & 77 & 106 & 87 & 49 & 103 & 850 & 8.33 & 15.8 \\
\hline HM -8468 & 50 & 74 & 55 & 44 & 96 & 843 & 9.30 & 18.9 \\
\hline 2429-3130 & 68 & 88 & 101 & 46 & 100 & 1171 & 10.77 & 18.1 \\
\hline No-6 & 62 & 97 & 82 & 48 & 98 & 904 & 9.20 & 17.6 \\
\hline NARC-2 & 30 & 21 & 77 & 48 & 101 & 262 & 10.97 & 18.7 \\
\hline Ajmeri & 52 & 91 & 80 & 46 & 100 & 2256 & 11.5 & 18.0 \\
\hline CV\% & 6.85 & 43.43 & 26.46 & 5.43 & 2.50 & 30.96 & 7.82 & 5.97 \\
\hline
\end{tabular}

Table 2. Mean values of different parameters Soybean genotypes during 2014 at NARC

\begin{tabular}{|c|c|c|c|c|c|c|c|c|}
\hline Entry No. & $\begin{array}{c}\text { Plant } \\
\text { Height } \\
(\mathbf{c m})\end{array}$ & $\begin{array}{c}\text { Plant/ } \\
\text { Plot } \\
\text { (No.) }\end{array}$ & $\begin{array}{c}\text { Pods/ } \\
\text { Plant } \\
\text { (No.) }\end{array}$ & $\begin{array}{c}\text { Days to } \\
\text { Flowering } \\
\text { (Days) }\end{array}$ & $\begin{array}{c}\text { Days of } \\
\text { Maturity } \\
\text { (Days) }\end{array}$ & $\begin{array}{c}\text { 100 Seed } \\
\text { Weight } \\
(\mathbf{g})\end{array}$ & $\begin{array}{c}\text { Seed } \\
\text { Yield } \\
(\mathbf{k g} / \mathbf{h a})\end{array}$ & $\begin{array}{c}\text { Oil } \\
\text { Content } \\
(\mathbf{\%})\end{array}$ \\
\hline Callend & 70 & 144 & 90 & 49 & 95 & 10.92 & 2109 & 17.5 \\
\hline SS-129 & 76 & 105 & 96 & 47 & 96 & 10.89 & 2493 & 17.4 \\
\hline E-1092 & 70 & 122 & 78 & 51 & 99 & 8.78 & 1805 & 16.4 \\
\hline Lochlon & 74 & 148 & 93 & 47 & 94 & 11.2 & 2264 & 18.7 \\
\hline E-1531 & 68 & 107 & 104 & 46 & 97 & 10.82 & 2207 & 12.6 \\
\hline No.3702 & 76 & 155 & 94 & 46 & 92 & 10.96 & 2289 & 17.6 \\
\hline Amcor & 63 & 129 & 106 & 46 & 96 & 10.2 & 2294 & 16.7 \\
\hline Aust 94-1 & 77 & 160 & 100 & 46 & 95 & 11.9 & 2215 & 18.4 \\
\hline TN-81-124 & 73 & 149 & 109 & 54 & 95 & 9.65 & 2247 & 17.1 \\
\hline HM-8468 & 76 & 99 & 119 & 46 & 91 & 11.76 & 2335 & 19.8 \\
\hline 2429-3130 & 72 & 133 & 104 & 45 & 96 & 13.76 & 2044 & 16.9 \\
\hline No-6 & 77 & 98 & 99 & 44 & 101 & 10.84 & 2106 & 17.8 \\
\hline NARC-2 & 62 & 118 & 72 & 40 & 90 & 10.47 & 2591 & 17.8 \\
\hline Ajmeri & 65 & 145 & 75 & 46 & 96 & 12.0 & 2502 & 18.2 \\
\hline CV\% & 10.52 & 63.48 & 35.74 & 5.99 & 46.37 & 9.71 & 24.79 & 7.89 \\
\hline
\end{tabular}

\section{Hundred seed weight}

A significant effect of genotypes was observed on hundred seed weight in both theyears. In 2013 hundred seed weight was ranged from 7.70 to $11.07 \mathrm{~g}$ (Table 1).
Maximum hundred seed weight was recorded in Ajmeri (11.5g), followed by Callend, E15-13, NARC-2 and 2429-3130 with hundred seed weight of $11.07,11.03,10.97$ and $10.77 \mathrm{~g}$ respectively. Minimum seed weight 
was recorded in Amcor (7.7g). In2014 the genotype 2429-3130 produced maximum hundred seed weight $(13.7 \mathrm{~g})$ followed by Ajmeri (12g) and HM-8468 (11.9g) whereas minimum seed weight was recorded in E1092 (8.7g) (Table 2). Our results are also similar to those of Ashraf et al. [29] who found significant effect of genotype on hundred seed weight.

\section{Oil contents}

The significant effect of genotype was also observed on oil content in both years. In 2013the oil content ranged from 15.8 to $18.9 \%$ (Table 1). Maximum oil content recorded in HM.8468 and E-15-13 (18. 9\%) followed by NARC-2 (18.7\%) and S-129 $(18.4 \%)$ whereas minimum oil content was determined in TN-81-124 with oil content of $15.8 \%$. The effect of genotypes on oil content was also significant in 2014. Maximum oil content was recorded in HM.8468 (19.8\%) and minimum oil content was determined in E-1092 (16.1\%). The results of this study also in line with previous studies Iqbal et al. [6]. In these studies they also observed significant variation among Soybean genotypes for oil content.

\section{Seed yield}

Seed yield is the ultimate goal and end product of all field crops. The data recoded on 14 entries of Soybean revealed significant difference for yield in both years. In 2013the maximum seed yield was recorded in Ajmeri $(2256 \mathrm{Kg} / \mathrm{h})$ followed by Callend (2249 $\mathrm{Kg} / \mathrm{ha}$ ) and E-1531, (2160 Kg/ha). Minimum seed yield was recorded in Amcor (576Kg/ha). In 2014, maximum seed yield was recorded in NARC-2 (2591 $\mathrm{Kg} / \mathrm{ha})$ followed by Ajmeri $(2502 \mathrm{Kg} / \mathrm{ha}), \mathrm{SS}-129$ $(2493 \mathrm{Kg} / \mathrm{ha})$ and HM-8468 (2335 Kg/ha) (Table 2). These findings are in accordance with those of $[6,15,16,19,30]$ who found significant differences among cultivars of Soybean.

\section{Conclusions}

Estimating genetic diversity among crops is pre-requisite for breeding program. In Pakistan, Soybean crop has negligible production and grown only in marginal fields for domestic consumption. Major hindrance for low adoption of the crop is due to absence of new elite Soybean varieties as traditional Soybean varieties imported in 1980s have low grain yield. Therefore, in the present study Soybean genotypes were evaluated to select high yielding early maturing lines for further utilization in Soybean crop improvement program. It is imperative to localize the crop which is one of the leading import commodities due to demand from poultry and feed industry and local edible oil production. We recommend wide scale germplasm characterization for selecting parental lines to develop climate smart, disease resistant and high yielding varieties. These high yielding and adaptable Soybean varieties will offer new opportunities to small farmers whose land remain noncultivated after wheat crop in Kharif season.

\section{Authors' contributions}

Conceived and designed the experiments: D Baig, M Arshad \& N Nawaz, Performed the experiments: D Baig, MA Khan \& N Nawaz, Contributed to reagents/ materials/ analysis tools: SA Jan, H Khurshid \& D Baig, Analyzed the data and wrote the manuscript: SA Jan \& H Khurshid.

\section{References}

1. Hartman GL, West ED \& Herman TK (2011). Crops that feed the world 2 . Soybean-Worldwide production, use, and constraints caused by pathogens and pests. Food Secur 3: 5-17.

2. Jan SA, Shinwari ZK \& Rabbani MA (2016). Morpho- biochemical evaluation of Brassica rapa sub-species for salt tolerance. Genetika 8(1): 323 -338. 
3. Khan Q, Khan AS, Khurshid H, Jan SA, Ahmad N, Khan SA, Shah SH, Saleem N, Ibrahim MI, Ilyas M \& Arif M (2016). Exploring durable genetic resistance against leaf rust through phenotypic characterization and LR34 linked STS marker in wheat germplasm. Biosci J 32 (4): 986-998.

4. Jan SA, Shinwari ZK \& Rabbani MA (2016). Agro-morphological and physiological responses of Brassica rapa ecotypes to salt stress. Pak J Bot 48(4): 1379-13.

5. Jan SA, Bibi N, Shinwari ZK, Rabbani MA, Ullah S, Qadir A \& Khan N (2017). Impact of salt, drought, heat and frost stresses on morpho-biochemical and physiological properties of Brassica species: An updated review. J Rural Dev Agri 2(1): 1-10.

6. Iqbal Z, Arshad M, Ashraf M, Mahmood $\mathrm{T} \&$ Waheed A (2008). Evaluation of Soybeen [Glycine $\max$ (L.) Merr.] germplasm for some important morphological traits using multivariate analysis. Pak J Bot 40(6): 2323-2328.

7. Ojo DK, Ajayi AO \& Oduwaye OA (2012). Genetic relationships among Soybean Accessions based on morphological and RAPDS Techniques. Pertanika J Trop Agric Sci 35(2): 237 248

8. Qadir A, Ali N, Jan SA, Rabbani MA, Shaheen A \& Khurshid H (2017). Estimating phenotypic diversity in diverse Fenugreek (Trigonella foenumgraceum L.) population through hmorphometric analysis. Int. J. Biosci 11(1): 274-283.

9. Brown-Guedira GL, Thompson JA, Nelson RL \& Warburton ML (2000). Evaluation of genetic diversity of Soybean introductions and North American ancestors using RAPD and SSR markers. Crop Sci 40: 815-823.
10. Jan SA, Shinwari ZK, Rabbani MA, Niaz IA \& Shah SH (2017). Assessment of quantitative agro-morphological variations among Brassica rapa diverse populations. Pak J Bot 49(2): 561-567.

11. Khatab AI \& Morsy A (2012). Evaluation of genetic relationshipsof some Soybean genotypes using morphological and molecular markers. Annals of Agric Sci Moshtohor 2: 35-39.

12. Qadir A, Ali N, Jan SA, Rabbani MA, Khurshid H, Nouman A \& Ullah $\mathrm{F}(2017)$. Characterization of agromorphological variation in exotic Fenugreek (Trigonella foenum-graecum L.) germplasm. J Bio Env Sci 10(3): 7179.

13. Khatab, I. A., Morsy, A. R., Fares, W. M., \& Kumamaru, T. (2016). Genetic Diversity of Soybean Genotypes revealed by Agro-morphological and SSR markers. J Fac Agri Kyushu Uni 61(1): 79-87.

14. Jan SA, Shinwari ZK, Rabbani MA, Khurshid H, Ibrahim MI, Adil M and Ilyas M (2017). Comparison of electrophoretic protein profiles of Brassica rapa sub-species brown sarson through SDS-PAGE method. Genetika 49 (1): 95-104.

15. Khan A, Rahim M \& Din QS (1993). High yielding varieties of Soybean for sowing in orchards and irrigated lands of Malakand Division [Pakistan]. Sarhad J Agri 9(6): 532-538.

16. Khan H, Bashir M, Amanullah, Iqbal N \& Ahmad T (2005). Evaluation of midseason Soybean varieties at Mansehra [Pakistan]. Sarhad J Agric 21(4): 531533.

17. Jin OY, Ho K, Kee S, Dong K, Kyun C, HoKi P \& Gon K (2007). A new Soybean cultivar, "Wonhwang" with small seed size and high yielding for sprout. Kor $J$ Breed Sci 39(1): 82. 
18. Jan SA, Shinwari ZK \& Rabbani MA (2016). Determining genetic divergence among Brassica rapa ecotypes through electrophoretic mobility of total seed proteins. J Animal Plant Sci 26(6): 17581764.

19. Akande SR, Owolade OF \& Ayanwole JA (2007). Field evaluation of Soybean varieties at IIorin in Southern guinea savanna ecology of Nigeria. Afr J Agri Res 2(8): 356-359.

20. Nawaz S, Chaudhry Z, Bibi A, Jan SA, Bibi K \& Asma (2015). AgroMorphological and Molecular Characterization of Local Tomato Cultivars Grown in Pakhal Region of Pakistan Using RAPD Markers. MiddleEast J Sci Res 23(5): 856-860.

21. Jan SA, Shinwari ZK, Rabbani M.A., Khurshid H \& Ahmad N (2017). Agromorphological studies revealed broad genetic structure of spatially distributed Brassica rapa populations. Pak J Bot 49(6): 2309-2312.

22. Saleem N, Jan SA, Atif MJ, Khurshid H, Khan SA \& Rabbani MA (2017). Multivariate Based Variability within Diverse Indian Mustard (Brassica juncea L.) Genotypes. Open J Gen 7: 69-83.

23. Jan SA, Shinwari ZK, Rabbani MA, Shah SH, Ibrahim MI \& Ilyas M (2016). Optimization of an efficient SDS-PAGE protocol for rapid protein analysis of Brassica rapa. J Bio Env Sci 9(2): 17-24.
24. Arif M, Khurshid H, Siddiqui SU, Jatoi SA, Jan SA, Ilyas M, Khan SA, Khan A, Ibrahim MI, Saleem N \& Ghafoor A (2015). Estimating spatial population structure through quantification of Oil content and phenotypic diversity in Pakistani Castor Bean (Ricinus communis L.) germplasm. Sci Technol Develop 34(3): 147-154.

25. Steel RGD \& Torrie JH (1980). Principles and procedure of statistics. McGraw Hill Book.

26. Burli AV, Dodake SS, Kamble AB \& Gare BN (2010). Genetic variability, heritability and correlation in Soybean. $J$ Maharashtra Agri Univ 35(2): 331-333.

27. Veni BK, Rani BP, Ramana MV (2008). Genetic divergence studies in Soybean (Glycine max, L.). Soybean-Res. Indore Ind 6: 77-80.

28. Arshad M, Ali N \& Ghafoor A (2006). Character correlation and path coefficient in Soybean (Glycin emax L.) Merrill. Pak J Bot 38(1): 121-130.

29. Ashraf MZ, Iqbal, Arshad M, Waheed A, Gulfaran MA, Chaudry Z \& Baig D (2010). Multi-environment response in seed yield of Soybean (Glycine max L. Merr), genotypes through GGE biplot technique. Pak J Bot 42(6): 3899-3905.

30. Storck L, Cargnelutti A, Lucio AD, Missio EL \& Rubin AL (2010). Experimental precision evaluation of Soybean cultivar yield trials. Ciencia-eAgrotetecnol 34(3): 572-578. 